\title{
Substrate disinfection methods on the production and nutritional composition of a wild oyster mushroom from the Amazon
}

\author{
Métodos de desinfecção do substrato na produção e composição \\ nutricional de um cogumelo ostra da Amazônia
}

\author{
Lorena Vieira Bentolila de Aguiar ${ }^{1} \mathbb{D}$, Ceci Sales-Campos ${ }^{1 *} \mathbb{D}$, Paula Romenya dos Santos Gouvêa ${ }^{1}$, \\ Bazilio Frasco Vianez ${ }^{1} \mathbb{D}$, Eustáquio Souza Dias $^{2} \mathbb{D}$, Larissa Ramos Chevreuil ${ }^{1} \mathbb{D}$
}

\author{
'Instituto Nacional de Pesquisas da Amazônia/INPA, Manaus, AM, Brasil \\ ¿Universidade Federal de Lavras/UFLA, Lavras, MG, Brasil \\ *Corresponding author: ceci@inpa.gov.br \\ Received in May 10, 2021 and approved in July 8, 2021
}

\begin{abstract}
One of the most expensive steps in mushroom production is the disinfection of the substrate. This study aimed to evaluate different methods of disinfecting various substrates used in the cultivation of Pleurotus ostreatus from the Amazon. P. ostreatus was grown under uncontrolled temperature conditions in a greenhouse (at approximately $30^{\circ} \mathrm{C}$ ) on substrates formulated with residues (seeds) of açaí and tucumã palm trees, Brazil nuts shell and pine sawdust. The different substrate disinfection treatments comprised autoclaving, immersion in hot water or immersion in calcium hydroxide (2\%). The chemical composition of residues, substrates, and mushrooms was analyzed. During cultivation, it was found that in the treatment with hot water, all the bags were contaminated, and treatment with calcium hydroxide inhibited the colonization and growth of the mushrooms. P. ostreatus grown on the autoclaved açaí substrate supplemented with tucumã had higher production. The highest percentage of fiber content was obtained when the mushrooms were cultivated in the pine substrate supplemented with Brazil nuts ( 32.68 to $33.65 \%$ ), and the highest protein content ( 20.03 to $20.88 \%$ ) was found in the mushrooms grown on açaí-based substrates. Considering that $P$. ostreatus showed higher productivity in autoclaved substrates, further studies should be performed to develop alternative methods of disinfecting substrates for the cultivation of mushrooms in the Amazon region, as well as, in other regions with a tropical climate. However, the cultivation of this mushroom is promising using some regional substrates, especially with açaí, which is one of the important natural products of the Amazon.
\end{abstract}

Index terms: Alternative substrates; biological efficiency; edible fungi; Pleurotus ostreatus.

\begin{abstract}
RESUMO
Uma das etapas que encarece a produção de cogumelos é a desinfecção dos substratos. Assim, este trabalho teve como objetivo avaliar diferentes métodos de desinfecção de diversos substratos utilizados no cultivo de um Pleurotus ostreatus da Amazônia. P. ostreatus foi cultivado sob condições de temperatura não controlada em casa de vegetação (aproximadamente $30^{\circ} \mathrm{C}$ ) em substratos formulados com resíduos (sementes) de palmeiras de açaí e tucumã, casca de castanha do Brasil e serragem de pinus. Diferentes tratamentos de desinfecção do substrato consistiram em autoclavagem, imersão em água quente e em hidróxido de cálcio (2\%). Foi analisada a composição química dos resíduos, substratos e cogumelos. Durante o cultivo, verificou-se que no tratamento com água quente, todos os sacos estavam contaminados e o tratamento com hidróxido de cálcio inibiu a colonização e o crescimento do cogumelo. $P$. ostreatus cultivado em substrato de açaí autoclavado e suplementado com tucumã apresentou maior produção. Os maiores teores de fibras totais foram obtidos nos cogumelos provenientes do cultivo em pinus, suplementado com castanha do Brasil (32,68 a 33,65\%) e os maiores teores de proteínas (20,03 a 20,88\%) nos substratos à base de açaí. Considerando que $P$. ostreatus apresentou maior produtividade nos substratos autoclavados, novos estudos deverão ser realizados com o objetivo de se desenvolver métodos alternativos de desinfecção de substratos para o cultivo de cogumelos na região amazônica, bem como em outras regiões de clima tropical. Contudo, o cultivo deste cogumelo mostrou-se promissor, utilizando-se substratos regionais, com ênfase para o açaí, um dos importantes produtos da Amazônia.
\end{abstract}

Termos para indexação: Substratos alternativos; eficiência biológica; fungos comestíveis; Pleurotus ostreatus.

\section{INTRODUCTION}

Traditionally, mushrooms are cultivated using lignocellulosic materials as substrates (Rugolo et al.,
2020). These materials are usually made from substances disposed of in the agricultural and wood industries, where large amounts of wastes are generated; the cultivation of mushrooms is a way to use the incompletely utilized raw 
materials (Sadh; Duhan; Duhan, 2018; Valenzuela-Cobos et al., 2019). Thus, mushroom cultivation can reduce the adverse environmental impacts caused by the disposal of these residues by transforming them into low-calorie products rich in nutrients and proteins (Singhal et al., 2019).

In mushroom cultivation, one of the most important and expensive steps is the disinfection and sterilization of the substrate to reduce contamination by other microorganisms and selectively grow the product of interest. Among the methods used, autoclaving is quite effective; however, it has a high cost in the production process (Xiong et al., 2019).

Substrate treatments include conventional methods, such as thermal (pasteurization with hot water or steam) and chemical disinfection (with formaldehyde, carbendazim, chlorine, hydrogen peroxide, and calcium hydroxide) (Rodriguez; Pecchia, 2017; Gowda; Manvi, 2019). Although they are not effective in the complete elimination of antagonistic microorganisms, they reduce the level of microorganisms sufficiently for cultivation (Dias, 2010).

Another limiting factor for mushroom producers in tropical regions is high temperature since many species or strains of commercial mushrooms are adapted to temperate climates; thus, an expensive temperature control system or the use of species or strains adapted to these temperatures is required. In this context, the genus Pleurotus contains species and even strains within a species, with different temperature requirements for fruiting (Gaitán-Hernández; Salmones, 2008).

Furthermore, the nutritional composition of mushrooms can be highly variable between species and strains of the same species, and can vary due to the cultivation conditions, degree of maturation of the fruiting body, structure of the mushroom (stem and stipe), substrate composition, harvest, and storage conditions (ValenzuelaCobos et al., 2019). Therefore, correctly selecting the strains and substrates for cultivation is important for successful fungiculture.

For substrates, it is important to choose locally available wastes. The northern region of Brazil is the largest producer of the açaí fruit (Instituto Brasileiro de Geografia e Estatística -IBGE, 2020). While processing açaí to obtain the pulp, $93 \%$ of the fruit is rejected as residue, which does not have any adequate use (Maranho; Paiva, 2012; Lima et al., 2021).

Another important product of the Amazon region is Brazil nuts. By comparing the components of the fruit of Brazil nuts (urchin, tegument plus almond), only $13.72 \%$ of the total mass corresponds to almonds, with the rest is inedible (Bitencourt et al., 2020). Another regionally appreciated fruit is tucumã. The edible part represents only $25 \%$ of the fruit, while the epicarp (peel) represents almost $30 \%$, and the endocarp (seed) constitutes about $45 \%$ of the fruit; this part is barely used (Ferreira et al., 2008), adding a considerable amount of residue.

Pinus is one of the genera in Brazil that significantly contributes as a source of wood to various industries, being essential in the pulp and lamination industries and sawmills. They are planted and used in all regions of Brazil, although it is more common in the southern region (Lima et al., 2016). Similar to other types of wood, Pinus, as raw material, is not completely used during industrial processes (Silva Júnior, 1993). The wood industry in the Amazon region uses materials inefficiently, where $15 \%$ to $50 \%$ of the raw material in wood processing is lost; thus, generating a large amount of waste (Sales-Campos; Abreu; Vianez, 2000).

Thus, this research was aimed to evaluate the production and quality of a strain of Pleurotus ostreatus from the Amazon (Brazil), using regional wastes and different disinfection methods.

\section{MATERIAL AND METHODS}

The lignocellulosic residues used in this study were tucumã palm seeds (Astrocaryum aculeatum), shells of Brazil nuts (Bertholletia excelsa), açaí palm seeds (Euterpe precatoria), and a mixture of pine sawdust (Pinus elliottii and Pinus taeda), collected from wood and agriculturebased industries in the State of Amazonas, Brazil. The pine sawdust was previously washed in water $(72 \mathrm{~h})$ to eliminate chemical constituents that could potentially inhibit the growth of the mushroom.

The Amazonian strain of Pleurotus ostreatus (Jacq.) P. Kumm (code 1467) was obtained from the Culture Collection of Agrosilvicultural Microorganisms of the National Institute for Amazon Research (INPA).

\section{Spawn preparation}

Initially, the strain of fungus was reactivated in PDA (Potato Dextrose Agar) medium and incubated in a BOD (Biological Oxygen Demand) incubator at $27^{\circ} \mathrm{C}$ till mycelia covered the plates completely to obtain the primary matrix. The secondary matrix was obtained from the primary matrix, inoculated under the same conditions. The tertiary matrix or spawn was prepared by using four different formulations, composed of $80 \%$ substrate-base (açaí or pinus), 18\% supplements (tucumã or Brazil nuts) and $2 \% \mathrm{CaCO}_{3}(\mathrm{pH}$ was adjusted to 6.0 ). Subsequently, the substrates were humidified 
until saturated with water and autoclaved at $121{ }^{\circ} \mathrm{C}$ for $45 \mathrm{~min}$ in glass flasks. After cooling, they were inoculated with the secondary matrix and incubated at $27{ }^{\circ} \mathrm{C}$ in the BOD incubator until complete colonization of the substrate by the fungus.

\section{Mushroom cultivation}

The substrates were formulated according to the methodology of Sales-Campos, Minhoni and Andrade (2010), and three different disinfection treatments of the substrates were tested, consisting of sterilization by autoclaving at $121{ }^{\circ} \mathrm{C}$ for $1 \mathrm{~h}$, immersion in $2 \%$ calcium hydroxide $\left(\mathrm{Ca}(\mathrm{OH})_{2}\right)$ for $24 \mathrm{~h}$, and immersion in hot water at $80-90{ }^{\circ} \mathrm{C}$ for $90 \mathrm{~min}$. The colonized spawn $(5 \% \mathrm{w} / \mathrm{w})$ was transferred to bags containing each type of substrate $(95 \% \mathrm{w} / \mathrm{w})$, with a final mass of $400 \mathrm{~g}$, in the laminar flow cabinet. The amount of the colonized spawn used (5\%) was to allow Pleurotus ostreatus to compete with contaminants, as some of the treatments could disinfect only partially. The inoculated bags were incubated at $27{ }^{\circ} \mathrm{C}$ until complete colonization (around 60 days, to maintain all treatments for the same duration and subject to the same conditions). Later, they were transferred to a production greenhouse under uncontrolled temperature conditions (environmental conditions of tropical regions, characterized by high temperatures and high relative humidity). The fruiting bodies produced were collected, dried (at $50{ }^{\circ} \mathrm{C}$ ), ground, and stored for further analysis. Visual analysis of the bags was performed daily to check for contaminations.

Productivity was determined by the biological efficiency, yield, and loss of organic matter (SalesCampos; Andrade, 2011).

\section{Physicochemical parameters and centesimal composition}

The moisture and dry matter content were determined by evaluating the weight difference after drying at $105^{\circ} \mathrm{C}$. The $\mathrm{pH}$ of the raw materials, substrates, and mushrooms was determined using a potentiometer, previously calibrated with buffers of $\mathrm{pH} 7$ and 4 , following the methodology recommended by the (IAL, 2008). Organic carbon content was measured using the Walkley Black method, according to Mendonça and Matos (2005). Ash content, lipid, total fiber, protein (obtained from the nitrogen content and converted by the factors 6.25 for the residues and substrates, and 4.38 for mushrooms), $\mathrm{pH}$, carbon, total and available carbohydrates, and metabolizable energy (calculated based on the values of proteins, available carbohydrates, and lipids) were determined according to the methodologies described in Sales-Campos et al. (2011).

\section{Statistical analysis}

A completely randomized experimental design was used for the treatments, using a $4 \times 3$ factorial scheme, consisting of four substrates (açaí + Brazil nuts, açaí + tucumã, pine + Brazil nuts, and pine + tucumã) and three disinfection methods (autoclaving, calcium hydroxide, and hot water), with 18 replicates and a total of 216 bags. The data were analyzed by performing ANOVA, and the means were compared by performing the Scott-Knott test at a level of significance of $5 \%$ using the SISVAR statistical program (version 5.6) (Ferreira, 2011).

\section{RESULTS AND DISCUSSION}

Mushroom production was conducted without temperature control during the rainy season in the Amazon region (February to May), with temperatures ranging from 25.2 to $32.7^{\circ} \mathrm{C}$ and an average of $29.65^{\circ} \mathrm{C}\left( \pm 1.57^{\circ} \mathrm{C}\right)$.

Autoclaved substrates had a low contamination rate, where only the substrate composed of pine sawdust, supplemented with Brazil nuts (P+BN AUT), showed $5.55 \%$ of the bags with severe contamination (which comprised more than $50 \%$ of the visibly compromised bags). All treatments with hot water showed some contamination, with the highest intensity observed in $\mathrm{P}+\mathrm{BN}$ HW, pine sawdust supplemented with tucumã $(\mathrm{P}+\mathrm{T}$ $\mathrm{HW})$ and açaí supplemented with Brazil nuts $(\mathrm{A}+\mathrm{BN}$ HW), where $33.33,27.78$ and $16.66 \%$, of the bags were contaminated, respectively.

Among the residues used, pine sawdust $(\mathrm{P})$ showed the highest carbon and lowest nitrogen content, resulting in a high $\mathrm{C} / \mathrm{N}$ ratio (Table 1). The residues of açaí (A), Brazil nuts $(\mathrm{BN})$, and tucumã $(\mathrm{T})$ presented the same nitrogen content and the cultivation substrates formulated with these residues $(\mathrm{A}+\mathrm{BN}$ and $\mathrm{A}+\mathrm{T})$ for all disinfection treatments. In the substrates composed of pine sawdust, the nitrogen concentration was not influenced by disinfection methods, with concentrations about two times lower than that in açaí (Table 1).

For the mushrooms, the carbon content remained around $40 \%$, while the nitrogen values varied from $3.35 \%$ to $4.87 \%$, being higher in the mushrooms from the açaí substrates, regardless of treatment or formulation (Table 1). The $\mathrm{C} / \mathrm{N}$ ratio was higher in mushrooms grown on pine substrates without the influence of supplementation with Brazil nuts and tucumã, or the disinfection methods. 
Table 1: Carbon $(\mathrm{C})$ and nitrogen $(\mathrm{N})$ content, $\mathrm{C} / \mathrm{N}$ ratio, $\mathrm{pH}$, and moisture content of residues, substrates, and mushrooms. AUT: autoclaved, HW: hot water, CA: calcium hydroxide.

\begin{tabular}{|c|c|c|c|c|c|c|}
\hline & & C (\%) & $\mathrm{N}(\%)$ & $\mathrm{C}: \mathrm{N}$ & $\mathrm{pH}$ & Moisture (\%) \\
\hline \multirow{4}{*}{ Residues } & Açaí (A) & $51.60 \pm 0.20 b$ & $0.45 \pm 0.00 a$ & $114.29 \pm 0.33 b$ & $5.69 \pm 0.01 b$ & $16.65 \pm 0.14 a$ \\
\hline & Brazil nut (BN) & $49.42 \pm 0.66 c$ & $0.45 \pm 0.00 a$ & $109.34 \pm 1.47 c$ & $6.22 \pm 0.01 a$ & $16.26 \pm 0.22 a$ \\
\hline & Pinus (P) & $54.37 \pm 0.86 a$ & $0.15 \pm 0.00 b$ & $361.62 \pm 5.01 \mathrm{a}$ & $4.62 \pm 0.01 c$ & $9.64 \pm 0.28 c$ \\
\hline & Tucumã (T) & $35.27 \pm 0.14 d$ & $0.45 \pm 0.00 \mathrm{a}$ & $77.99 \pm 0.39 d$ & $4.14 \pm 0.01 \mathrm{~d}$ & $11.54 \pm 0.39 b$ \\
\hline \multirow{12}{*}{ Substrates } & $A+B N$ AUT & $49.01 \pm 0.74 c$ & $0.45 \pm 0.00 a$ & $108.77 \pm 1.82 \mathrm{~d}$ & $6.66 \pm 0.01 f$ & $65.33 \pm 0.31 \mathrm{e}$ \\
\hline & $\mathrm{A}+\mathrm{BN} \mathrm{HW}$ & $49.37 \pm 0.41 c$ & $0.45 \pm 0.00 a$ & $108.93 \pm 0.76 d$ & $6.35 \pm 0.01 \mathrm{~h}$ & $68.80 \pm 0.11 b$ \\
\hline & $A+B N C A$ & $49.07 \pm 0.18 c$ & $0.45 \pm 0.00 a$ & $109.11 \pm 0.49 d$ & $8.46 \pm 0.01 b$ & $64.65 \pm 0.19 f$ \\
\hline & $\mathrm{A}+\mathrm{T}$ AUT & $46.83 \pm 0.20 d$ & $0.45 \pm 0.00 a$ & $103.65 \pm 0.36 \mathrm{e}$ & $6.73 \pm 0.01 \mathrm{e}$ & $63.58 \pm 0.29 g$ \\
\hline & $\mathrm{A}+\mathrm{T} \mathrm{HW}$ & $46.96 \pm 0.23 d$ & $0.45 \pm 0.00 a$ & $104.19 \pm 0.87 \mathrm{e}$ & $6.32 \pm 0.01 \mathrm{~h}$ & $67.51 \pm 0.46 c$ \\
\hline & $\mathrm{A}+\mathrm{T} C \mathrm{~A}$ & $46.47 \pm 0.38 d$ & $0.45 \pm 0.00 a$ & $103.21 \pm 0.92 \mathrm{e}$ & $8.31 \pm 0.01 d$ & $66.57 \pm 0.21 d$ \\
\hline & $\mathrm{P}+\mathrm{BN}$ AUT & $53.64 \pm 0.22 a$ & $0.22 \pm 0.00 b$ & $239.32 \pm 2.20 a$ & $6.66 \pm 0.01 f$ & $67.61 \pm 0.77 c$ \\
\hline & $\mathrm{P}+\mathrm{BN} H W$ & $53.30 \pm 0.47 a$ & $0.22 \pm 0.00 b$ & $236.04 \pm 1.81 \mathrm{a}$ & $6.28 \pm 0.01 h$ & $69.34 \pm 0.16 b$ \\
\hline & $\mathrm{P}+\mathrm{BN} C \mathrm{CA}$ & $53.57 \pm 0.34 a$ & $0.22 \pm 0.00 \mathrm{~b}$ & $237.70 \pm 2.33 a$ & $8.65 \pm 0.02 \mathrm{a}$ & $67.35 \pm 0.42 c$ \\
\hline & $\mathrm{P}+\mathrm{T}$ AUT & $50.75 \pm 0.43 b$ & $0.22 \pm 0.00 b$ & $227.51 \pm 2.48 b$ & $6.40 \pm 0.01 \mathrm{~g}$ & $66.65 \pm 0.29 d$ \\
\hline & $\mathrm{P}+\mathrm{T} \mathrm{HW}$ & $50.68 \pm 0.59 b$ & $0.22 \pm 0.00 b$ & $224.21 \pm 2.93 c$ & $6.12 \pm 0.01 \mathrm{i}$ & $69.94 \pm 0.08 a$ \\
\hline & $\mathrm{P}+\mathrm{T} C \mathrm{~A}$ & $50.31 \pm 0.43 b$ & $0.22 \pm 0.00 \mathrm{~b}$ & $222.84 \pm 1.81 \mathrm{c}$ & $8.33 \pm 0.01 c$ & $70.10 \pm 0.29 a$ \\
\hline \multirow{8}{*}{ Mushrooms } & $A+B N$ AUT & $42.71 \pm 0.16 a$ & $4.87 \pm 0.09 a$ & $8.75 \pm 0.12 b$ & $6.10 \pm 0.01 d$ & $92.59 \pm 1.83 a$ \\
\hline & $\mathrm{A}+\mathrm{BN} \mathrm{HW}$ & $41.65 \pm 0.21 b$ & $4.68 \pm 0.00 a$ & $8.90 \pm 0.05 b$ & $6.39 \pm 0.01 \mathrm{a}$ & $92.83 \pm 2.25 \mathrm{a}$ \\
\hline & $A+T$ AUT & $42.32 \pm 0.37 a$ & $4.83 \pm 0.15 a$ & $8.76 \pm 0.33 b$ & $6.09 \pm 0.01 \mathrm{e}$ & $92.39 \pm 0.92 a$ \\
\hline & $\mathrm{A}+\mathrm{T} \mathrm{HW}$ & $40.77 \pm 0.32 c$ & $4.78 \pm 0.09 a$ & $8.53 \pm 0.16 b$ & $6.32 \pm 0.01 b$ & $93.29 \pm 2.79 a$ \\
\hline & $\mathrm{P}+\mathrm{BN}$ AUT & $42.84 \pm 0.25 a$ & $3.52 \pm 0.09 b$ & $12.17 \pm 0.39 a$ & $6.33 \pm 0.02 b$ & $90.87 \pm 2.03 b$ \\
\hline & $\mathrm{P}+\mathrm{BN} \mathrm{HW}$ & $40.61 \pm 0.30 c$ & $3.36 \pm 0.08 c$ & $12.10 \pm 0.34 \mathrm{a}$ & $6.12 \pm 0.01 d$ & $90.73 \pm 2.57 b$ \\
\hline & $\mathrm{P}+\mathrm{T}$ AUT & $41.24 \pm 0.22 b$ & $3.35 \pm 0.11 c$ & $12.31 \pm 0.34 \mathrm{a}$ & $6.31 \pm 0.01 b$ & $94.08 \pm 0.90 a$ \\
\hline & $\mathrm{P}+\mathrm{T} H W$ & $41.44 \pm 0.55 b$ & $3.51 \pm 0.09 b$ & $11.81 \pm 0.41 \mathrm{a}$ & $6.19 \pm 0.01 c$ & $92.60 \pm 1.10 a$ \\
\hline
\end{tabular}

Means followed by the same letter in the columns do not differ statistically from one another by Scott-Knott at 5\% significance.

For the experimental condition involving the treatment of substrates with calcium hydroxide, there was no colonization of the substrate and, consequently, mushroom growth. Therefore, it was not possible to perform any physicochemical analyses or obtain values for the production and centesimal composition.

Carbon and nitrogen are the main nutrients required by mushrooms for growth, where carbon is essential for the synthesis of macromolecules and energy supply, and nitrogen is critical for protein synthesis and cellular activities (Chang; Miles, 2004; Anike; Yusuf; Isikhuemhen, 2016).

Agricultural wastes from crops like maize, wheat, barley, lentil, sugarcane, and rice residues, are regularly used for oyster mushroom cultivation and have been reported to have nitrogen levels ranging from $0.38 \%$ to $1.29 \%$ (Cueva; Monzón, 2014). Upon comparing the nitrogen levels from the wastes of those crops to the formulated substrates used in this study, it was found that supplementation with BN and $\mathrm{T}$ did not sufficiently increase the nitrogen content.

The recommended $\mathrm{C} / \mathrm{N}$ ratio of substrates for growing mushrooms should range from $75: 1$ to $80: 1$, but ratios between $32: 1$ and 150:1 were also reported to be effective (Chang; Miles, 2004), corroborating with the results of açaí-based substrates.

The residues had $\mathrm{pH}$ values between 4.14 and 6.22. After disinfestation, the $\mathrm{pH}$ of the substrates ranged from 6.12 to 6.73 for hot water and autoclave treatments, whereas the alkaline treatment resulted in a higher $\mathrm{pH}$, with values above 8.0 (Table 1). 
Sardar et al. (2015) observed that a $\mathrm{pH}$ of 6.0 was ideal for the growth of Pleurotus spp.; however, they had also reported that the mushrooms could grow and adapt to $\mathrm{pH}$ ranging from 5.0 to 8.0. Colavolpe, Mejía and Albertó (2014) obtained high productivity when cultivating $P$. ostreatus on different substrates treated with alkaline water. In contrast, Khan et al. (2013), when testing different concentrations of calcium hydroxide $(0$, 2,4 , and $6 \%$ ), found lower production of Pleurotus spp. in the cotton waste substrate with higher $\mathrm{pH}$ and a higher concentration of calcium hydroxide.

The substrates presented a moisture content ranging from 63.58 to $70.10 \%$ (Table 1) and thus were suitable for mushroom cultivation. Substrates should have a moisture range of 50 to $75 \%$ to allow mushroom development and not negatively affect oxygen availability (Chang; Miles, 2004). The moisture content of fresh mushrooms remained in the $90 \%$ range for all substrates tested (Table 1), which was within the moisture range reported in the literature (Rahman et al., 2012).

The protein content of the $\mathrm{A}, \mathrm{BN}$, and $\mathrm{T}$ residues was higher (by about three times) than that in $\mathrm{P}$, whereas the residues used as supplements (BN and $\mathrm{T}$ ) did not show differences in the protein content in the substrates $\mathrm{A}+\mathrm{BN}$ or $\mathrm{A}+\mathrm{T}(2.83 \%)$ and did not have any protein increment (Table 2).

In contrast, pine-based substrates $(\mathrm{P}+\mathrm{BN}$ and $\mathrm{P}+\mathrm{T})$ showed an increase in protein content with the addition of $\mathrm{BN}$ and $\mathrm{T}$ for all the disinfection methods (Table 2). Protein content in mushrooms was about $25 \%$ higher when grown on açaí substrates than in other substrates, with no significant difference between the disinfection treatments (Table 2).

Sales-Campos et al. (2011) found protein percentages ranging from 16.12 to $21.16 \%$ in the fruiting bodies of $P$. ostreatus grown on different sawdust-based substrates. Sardar et al. (2017) also obtained values between $18.93 \%$ (sawdust) and $25.36 \%$ (cotton residue) for P. eryngii.

The Pleurotus ostreatus and P. cystidiosus, when grown on different formulations with sawdust, corncob, and sugarcane bagasse, showed a positive correlation between the protein content in mushrooms and substrates before and after fungal cultivation (Hoa; Wang; Wang, 2015). Additionally, according to Silva et al. (2007), the non-protein nitrogen content had a similar effect. Therefore, the correlation was possibly between nitrogen content in the substrate and protein content in the mushroom.

Regarding lipids, the residue of $\mathrm{T}$ had the highest content, followed by that of $P$. The high value of lipids in $\mathrm{P}$ was due to the presence of a considerable amount of resins, waxes, and essential oils in the plant material, which was not completely washed even after immersing the residue in water (Vogelmann; Prevedello; Reichert, 2015). Consequently, all substrates supplemented with tucumã had a high lipid content, regardless of the disinfection method. For mushrooms, pine-based substrates had higher levels of lipids compared to those grown on other substrates (Table 2).

In general, the lipid content values found in this study were similar to those reported by Dundar, Acay and Yildiz, (2009), who observed lipid content ranging from 2.45 to $3.15 \%$ for oyster mushroom grown on soybean, corn, wheat, and cotton stalk substrates.

Pine sawdust and Brazil nut residues had the highest fiber content, justifying a higher content of fiber in the mushroom substrates containing these residues, especially in mushrooms grown on $\mathrm{P}+\mathrm{BN}, \mathrm{P}+\mathrm{T}$, and $\mathrm{A}+\mathrm{BN}$ (Table 2). The high fiber content reported for Pinus may be due to the higher content of components such as lignin and hemicellulose, characteristic of wood waste.

Sales-Campos et al. (2010) obtained similar results for fiber content, which varied from 18.89 to $31.30 \%$. However, unlike in the present study, rich fiber substrates do not necessarily produce rich fiber mushrooms; for example, marupá sawdust, which is a rich fiber substrate (74.05\%), produced poor fiber mushrooms (18.89\%).

The total carbohydrate in the residues ranged from 55.56 to $82.85 \%$, with a high percentage in pine residues, which was associated with high fiber content. However, the available carbohydrate content in pine residue was the lowest (Table 2). The highest percentages of total carbohydrates were observed in the substrates supplemented with BN. Additionally, among the disinfection methods used, HW provided the highest total carbohydrate content (Table 2). Mushrooms grown on pine-based substrates had the highest total carbohydrate content, which might have been associated with the high fiber content of the wood residue (Table 2).

The available carbohydrates in the cultivation substrate showed high variation among different residues (A and $\mathrm{P}$ ), supplementation (BN and $\mathrm{T}$ ), and disinfection methods (Table 2). For the mushrooms, the available carbohydrate content was higher in the fruiting bodies from the açaí-based substrates than those grown on other substrates (Table 2).

The level of carbohydrates in the mushrooms recorded in this study was similar to the values reported by Rahman et al. (2012), where 39.44 to $48.45 \%$ of carbohydrates were reported for $P$. ostreatus grown on rice straw supplemented with wheat bran. 
Table 2: Nutritional composition of residues, substrates, and mushrooms of Pleurotus ostreatus. AUT: autoclaved, HW: hot water, CA: calcium hydroxide.

\begin{tabular}{|c|c|c|c|c|c|c|c|}
\hline & & $\begin{array}{c}\text { Protein } \\
(\%)\end{array}$ & $\begin{array}{l}\text { Lipids } \\
\text { (\%) }\end{array}$ & $\begin{array}{c}\text { Total fibers } \\
\text { (\%) }\end{array}$ & $\begin{array}{c}\text { Total } \\
\text { carbohydrates } \\
(\%) \\
\end{array}$ & $\begin{array}{c}\text { Available } \\
\text { carbohydrates } \\
(\%)\end{array}$ & $\begin{array}{l}\text { Metabolizable } \\
\text { energy } \\
\left(\mathrm{kcal}^{\left.100 \mathrm{~g}^{-1}\right)}\right. \\
\end{array}$ \\
\hline \multirow{4}{*}{ Residues } & Açaí (A) & $2.82 \pm 0.00 a$ & $1.32 \pm 0.08 c$ & $42.42 \pm 1.56 c$ & $77.98 \pm 0.09 c$ & $36.05 \pm 1.63 a$ & $167.41 \pm 6.28 b$ \\
\hline & Brazil Nut (BN) & $2.83 \pm 0.00 \mathrm{a}$ & $0.34 \pm 0.03 d$ & $54.27 \pm 1.56 b$ & $78.90 \pm 0.24 b$ & $24.62 \pm 1.77 c$ & $112.94 \pm 7.00 \mathrm{c}$ \\
\hline & Pinus (P) & $0.94 \pm 0.00 \mathrm{~b}$ & $6.38 \pm 0.21 b$ & $70.73 \pm 0.68 a$ & $82.85 \pm 0.42 a$ & $7.07 \pm 0.70 \mathrm{~d}$ & $89.46 \pm 1.97 d$ \\
\hline & Tucumã (T) & $2.82 \pm 0.00 \mathrm{a}$ & $28.83 \pm 0.17 a$ & $24.03 \pm 0.09 d$ & $55.56 \pm 0.56 d$ & $25.02 \pm 0.99 b$ & $371.78 \pm 3.48 a$ \\
\hline \multirow{12}{*}{ Substrates } & & $2.81 \pm 0.01 \mathrm{~b}$ & $1.19 \pm 0.09 g$ & 45.0 & $78.75 \pm 0.14 \mathrm{e}$ & $33.62 \pm 0.80 c$ & $81 \mathrm{~d}$ \\
\hline & A+BN HW & $2.83 \pm 0.00 a$ & $1.33 \pm 0.12 \mathrm{~g}$ & $45.07 \pm 1.08 c$ & $84.80 \pm 0.43 b$ & $40.26 \pm 1.23 b$ & $184.37 \pm 4.12 c$ \\
\hline & $A+B N C A$ & $2.81 \pm 0.01 \mathrm{~b}$ & $1.62 \pm 0.06 f$ & $45.52 \pm 1.28 c$ & $79.90 \pm 0.07 d$ & $34.45 \pm 1.32 c$ & 163.62 \\
\hline & $\mathrm{A}+\mathrm{T} A U T$ & $2.82 \pm 0.01 \mathrm{a}$ & $7.97 \pm 0.02 c$ & $41.36 \pm 1.01 \mathrm{~d}$ & $75.32 \pm$ & $\pm 1.10 c$ & $35 a$ \\
\hline & & 2.8 & $d$ & $8 d$ & $86.06 \pm 0.19 a$ & $19 \mathrm{a}$ & $27 \mathrm{~b}$ \\
\hline & $A+T C A$ & $2.81 \pm 0.00 \mathrm{~b}$ & $7.67 \pm 0.15 d$ & $41.90 \pm 1.34 \mathrm{~d}$ & $68.81 \pm 1.05 i$ & $27.23 \pm 1.97 d$ & $189.24 \pm 6.63 c$ \\
\hline & $\mathrm{P}+\mathrm{BN}$ AUT & $1.40 \pm 0.01 d$ & $4.53 \pm 0.09 e$ & $66.38 \pm 1.02 a$ & $81.20 \pm 0.12 c$ & $15.08 \pm 0.95 f$ & $106.71 \pm 4.34 \mathrm{~g}$ \\
\hline & P+BN HW & $1.41 \pm 0.00 c$ & $4.61 \pm 0.26 \mathrm{e}$ & $65.38 \pm 0.54 a$ & $86.08 \pm 0.28 a$ & $20.81 \pm 0.81$ e & $130.41 \pm 0.91 f$ \\
\hline & $\mathrm{P}+\mathrm{BN} C \mathrm{CA}$ & $1.41 \pm 0.01 c$ & $4.72 \pm 0.05 \mathrm{e}$ & $66.77 \pm 1.30 \mathrm{a}$ & $72.16 \pm 0.85 h$ & $8.21 \pm 2.24 \mathrm{~h}$ & $\pm 8.74 \mathrm{~h}$ \\
\hline & $\mathrm{P}+\mathrm{T}$ AUT & $1.39 \pm 0.02 d$ & $10.97 \pm 0.16 b$ & $56.72 \pm 0.67 b$ & $75.32 \pm 0.11 \mathrm{~g}$ & $18.70 \pm 0.60 \mathrm{e}$ & $179.09 \pm 2.14 \mathrm{c}$ \\
\hline & $\mathrm{P}+\mathrm{THW}$ & $1.41 \pm 0.00 c$ & $10.95 \pm 0.04 b$ & $57.18 \pm 0.41 b$ & $76.94 \pm 0.12 f$ & $20.76 \pm 0.88 \mathrm{e}$ & $187.22 \pm 3.87 c$ \\
\hline & $\mathrm{P}+\mathrm{T} C \mathrm{~A}$ & $1.41 \pm 0.00 c$ & $11.18 \pm 0.06 a$ & $56.82 \pm 1.02 b$ & $66.71 \pm 0.32 j$ & $9.88 \pm 0.70 \mathrm{~g}$ & $145.79 \pm 2.84 \mathrm{e}$ \\
\hline \multirow{8}{*}{ Mushrooms } & A+BN AUT & $20.88 \pm 0.37 a$ & $2.49 \pm 0.05 d$ & $11.22 \pm 0.44 d$ & $59.31 \pm 0.21 c$ & $47.96 \pm 0.59 a$ & $297.77 \pm 3.24 b$ \\
\hline & $\mathrm{A}+\mathrm{BN} \mathrm{HW}$ & $20.03 \pm 0.01 \mathrm{a}$ & $2.92 \pm 0.05 c$ & $11.27 \pm 0.27 d$ & $58.00 \pm 0.59 d$ & $46.65 \pm 0.36 b$ & $295.65 \pm 1.26 b$ \\
\hline & A+T AUT & $20.69 \pm 0.63 a$ & $2.90 \pm 0.03 c$ & $9.58 \pm 0.48 d$ & $58.53 \pm 0.26 d$ & $48.69 \pm 0.36 a$ & $300.95 \pm 1.67 b$ \\
\hline & A+T HW & $20.45 \pm 0.37 a$ & $2.98 \pm 0.04 c$ & $9.98 \pm 0.09 d$ & $59.31 \pm 0.38 c$ & $49.40 \pm 0.39 a$ & $306.21 \pm 0.86 a$ \\
\hline & $\mathrm{P}+\mathrm{BN}$ AUT & $15.07 \pm 0.40 b$ & $2.99 \pm 0.07 c$ & $32.68 \pm 1.44 b$ & $64.88 \pm 0.26 b$ & $32.93 \pm 1.50 \mathrm{~d}$ & $218.96 \pm 5.63 \mathrm{e}$ \\
\hline & P+BN HW & $14.37 \pm 0.33 c$ & $3.53 \pm 0.09 a$ & $33.65 \pm 0.63 a$ & $64.72 \pm 0.63 b$ & $30.83 \pm 0.05 e$ & $212.46 \pm 2.21 f$ \\
\hline & P+TAUT & $14.34 \pm 0.47 c$ & $3.26 \pm 0.14 b$ & $23.10 \pm 1.11 c$ & $66.89 \pm 0.61 a$ & $44.03 \pm 0.60 c$ & $263.00 \pm 4.34 c$ \\
\hline & $\mathrm{P}+\mathrm{THW}$ & $15.02 \pm 0.41 b$ & $3.14 \pm 0.05 b$ & $22.06 \pm 1.31 \mathrm{c}$ & $64.58 \pm 0.36 b$ & $42.07 \pm 1.11 \mathrm{c}$ & $256.63 \pm 6.71 \mathrm{~d}$ \\
\hline
\end{tabular}

Means followed by the same letter in the columns do not differ statistically from one another by Scott-Knott at $5 \%$ significance.

Regarding the metabolizable energy ( $\mathrm{kcal} 100 \mathrm{~g}^{-1}$ ), the tucumã residue had the highest calories due to the high lipid content in this residue. Consequently, substrates supplemented with tucumã showed the highest caloric values (Table 2). For mushrooms, the highest caloric value was observed when grown on the substrate $\mathrm{A}+\mathrm{T}$ (Table 2). Information about energy and other nutritional compositions in mushrooms is of great interest for their use as healthy foods and food products (Ulziijargal; Mau, 2011).

Among the production parameters, the loss of organic matter (LOM), which indicated the substrate decomposition by $P$. ostreatus, ranged from $20.1 \%$ to $45.6 \%$, with the highest values observed for the autoclaved açaí-based substrates (Figure 1A). The biological efficiency (BE) ranged from 16.4 to $57.3 \%$, with the highest values obtained for autoclaved substrates supplemented with tucumã (Figure 1B). The same trend was observed for the yield, with high values for the autoclaved substrate of açaí supplemented with tucumã (Figure 1C).

Bernabé-González and Cayetano-Catarino (2009) observed a higher BE for $P$. pulmonarius when cultivated on Musa paradisiaca (banana) leaves treated with calcium hydroxide (120.1\%), but found no difference between the disinfection treatments (immersion in hot water at $80{ }^{\circ} \mathrm{C}$ for $1 \mathrm{~h}$ or in $2 \%$ calcium hydroxide for $24 \mathrm{~h}$ ) in the $\mathrm{BE}$ for P. pulmonarius cultivated on Chrysalidocarpus lutescens (palmareca) leaves. 

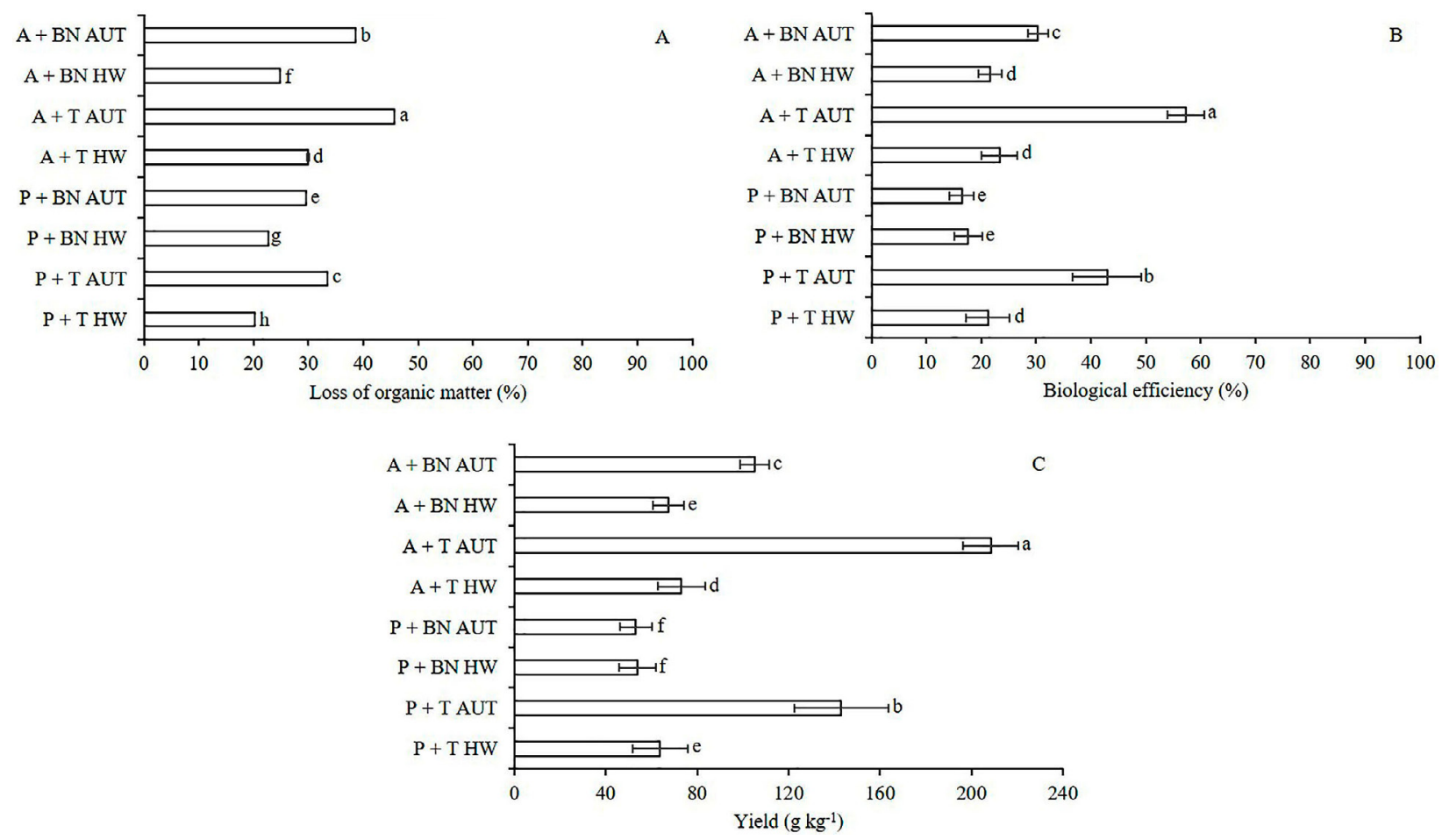

Figure 1: Shown are bar plots with the mean $( \pm S D)$ of Pleurotus ostreatus cultivated on substrates after different disinfection treatments with three productive parameters; A: loss of organic matter, B: biological efficiency, and C: yield. A+BN: açaí + Brazil nut, A+T: açaí + tucumã, P+BN: pine + Brazil nut, P+T: pine + tucumã. AUT: autoclaved, HW: hot water. Bars with the same letter do not differ statistically from one another as per the Scott-Knott test at a level of significance of $5 \%$.

Mejía and Albertó (2013), when cultivating $P$. ostreatus on wheat straw, observed that immersion in hot water reduced production by up to $20 \%$ when compared to other disinfection treatments, which might have been due to the loss of water-soluble nutrients by washing.

According to Gume, Muleta and Abate, (2013), oyster mushroom cultivation should result in $\mathrm{BE}$ values around or above $40 \%$. However, although the BE expresses the bioconversion of the substrate in mushrooms, yield or productivity are parameters more meaningful for producers since these parameters can be observed directly and objectively. Additionally, Siqueira et al. (2011) reported values above $10 \%$ as the minimum to have a good yield for oyster mushroom production. Nowadays, oyster mushroom growers expect to have $15 \%$ to $20 \%$ productivity.

Akhter, Chowdhury and Aminuzzaman (2017) reported higher production of $P$. ostreatus in the substrate treated with hot water at $80^{\circ} \mathrm{C}$ for $3 \mathrm{~h}$, compared to the substrates treated at 60 or $100^{\circ} \mathrm{C}$ for 1,2 , or $3 \mathrm{~h}$. Immersion in hot water to reduce contaminants (microorganisms) is one of the most popular techniques. It is used worldwide by producers and is an inexpensive and easy-to-implement technique (Mejia; Albertó, 2013). However, autoclaving is the most effective method for eliminating microorganisms but requires huge investment, making it difficult to be implemented for cultivation in underdeveloped regions (Nunes et al., 2017).

Thus, treatment of substrates using hot water can be effective in producing mushrooms in rural areas (Akhter; Chowdhury; Aminuzzaman, 2017) if it is wellexecuted and raw materials are used appropriately. Other alternatives to the autoclaving system are composting or pasteurization; these methods have provided good results in the cultivation of mushrooms at a lower cost (compared to autoclaving) and without eliminating beneficial microorganisms present in the substrate (Gowda; Manvi, 2019). The choice of the substrate used in mushroom cultivation is extremely important since it influences the centesimal composition of the mushrooms and allows the optimization of production according to the desired nutritional characteristics. 


\section{CONCLUSIONS}

Autoclaving is the most efficient method of disinfection, providing higher mushroom productivity. However, in case of insufficient investment in infrastructure and equipment and a need to reduce the energy costs, it is suggested to use the açaí-based substrate treated with hot water for the cultivation of $P$. ostreatus in the Amazon region.

\section{ACKNOWLEDGMENTS}

We are grateful to the Conselho Nacional de Desenvolvimento Científico e Tecnológico (CNPq, Projeto Universal $n^{\circ} 461729 / 2014-8$ ), Coordenação de Aperfeiçoamento de Pessoal de Nível Superior (CAPES - Projeto Pró-Amazônia n ${ }^{\circ}$ 3251/2013) and Fundação de Amparo à Pesquisa do Estado do Amazonas (FAPEAM Projeto $n^{\circ} 062.00648 / 2015$ ) for research funding and scholarships.

\section{REFERENCES}

AKHTER, K.; CHOWDHURY, M. S. M.; AMINUZZAMAN, F. $M$. Effect of sterilization of substrate by hot water treatment on prevalence of contaminants and yield attributes of oyster mushroom (Pleurotus ostreatus). Scholars Journal of Agriculture and Veterinary Sciences, 4(11):464-471, 2017.

ANIKE, F. N.; YUSUF, M.; ISIKHUEMHEN, O. S. Co-substrating of peanut shells with cornstalks enhances biodegradation by Pleurotus ostreatus. Journal of Bioremediation and Biodegradation, 7(1):1-7, 2016.

BERNABÉ-GONZÁLEZ, T.; CAYETANO-CATARINO, M. Cultivation of Pleurotus pulmonarius on substrates treated by immersion in alkaline water in Guerrero, Mexico. Micologia Aplicada International, 21(1):19-23, 2009.

BITENCOURT, M. A. F. et al. Pós-colheita, morfometria e rendimento de Castanhas-do-Brasil da Região Amazônica. Alimentos: Ciência, Tecnologia e Meio Ambiente, 1(10):13-38, 2020.

CHANG, S. T.; MILES; P. G. Mushrooms: Cultivation, nutritional value, medicinal effect, and environmental impact. Flórida, EUA: CRC Press LLC, 2004. 480p.

COLAVOLPE, M. B.; MEjÍA, S. J.; ALBERTÓ, E. Efficiency of treatments for controlling Trichoderma spp during spawning in cultivation of lignicolous mushrooms. Brazilian Journal of Microbiology, 45(4):1263-1270, 2014.
CUEVA, M. B. R.; MONZÓN, A. H. Evaluación de residuos agrícolas para la producción del hongo Pleurotus ostreatus. ICIDCA sobre los derivados de la caña de azúcar, 48(1):54-59, 2014.

DIAS, E. S. Mushroom cultivation in Brazil: Challenges and potential for growth. Ciência e Agrotecnologia, 34(4):795803, 2010.

DUNDAR, A.; ACAY, H.; YILDIZ, A. Effect of using different lignocellulosic wastes for cultivation of Pleurotus ostreatus (Jacq.) P. Kumm. on mushroom yield, chemical composition and nutritional value. African Journal of Biotechnology, 8(4):662-666, 2009.

FERREIRA, D. F. Sisvar: A computer statistical analysis system. Ciência e Agrotecnologia, 35(6):1039-1042, 2011.

FERREIRA, E. S. et al. Caracterização físico-química do fruto e do óleo extraído de tucumã (Astrocaryum vulgare mart). Alimentos e Nutrição, 19(4):427-433, 2008.

GAITÁN-HERNÁNDEZ, R.; SALMONES, D. Obtaining and characterizing Pleurotus ostreatus strains for commercial cultivation under warm environmental conditions. Scientia Horticulturae, 118(2):106-110, 2008.

GOWDA, N. A. N.; MANVI, D. Agro-residues disinfection methods for mushroom cultivation. Agricultural Reviews, 40(2):93-103, 2019.

GUME, B.; MULETA, D.; ABATE, D. Evaluation of locally available substrates for cultivation of oyster mushroom (Pleurotus ostreatus) in Jimma, Ethiopia. African Journal of Microbiology Research, 7(20):2228-2237, 2013.

HOA, H. T.; WANG, C. L.; WANG, C. H. The Effects of different substrates on the growth, yield, and nutritional composition of two oyster mushrooms (Pleurotus ostreatus and Pleurotus cystidiosus). Mycobiology, 43(4):423-434, 2015.

INSTITUTO ADOLFO LUTZ - IAL. Métodos físico-químicos para análise de alimentos. 4a ed. 1a ed. digital. São Paulo: Instituto Adolfo Lutz - IAL, 2008. 1020p.

INSTITUTO BRASILEIRO DE GEOGRAFIA E ESTATÍSTICA - IBGE. Açaí - Inovações na cadeia do açaí - Rastreabilidade. 2020. Available in: <https://www.conab.gov.br/info-agro/analisesdo-mercado-agropecuario-e-extrativista/analises-domercado/historico-mensal-de-sociobiodiversidade/item/ download/36551_a84e3de8047dbad0c54f08ad98e1ba6b>. Access in: June, 4, 2021.

KHAN, M. W. et al. Effect of different levels of lime and $\mathrm{pH}$ on mycelial growth and production efficiency of oyster mushroom (Pleurotus spp.). Pakistan Journal of Botany, 45(1):297-302, 2013. 
LIMA, E. C. S. et al. Optimization of the inulin aqueous extraction process from the açaí (Euterpe oleracea, Mart.) seed. Food Science and Technology, Ahead of Print, 2021.

LIMA, M. C. D. Biomass and carbon stock from Pinus caribaea var. hondurensis under homogenus stands in southwest Bahia, Brazil. Ciência Rural, 46(6):957-962, 2016.

MARANHO, A. S.; PAIVA, A. V. Produção de mudas de Physocalymma scaberrium em substratos compostos por diferentes porcentagens de resíduo orgânico de açaí. Revista Floresta, 42(2):399-408, 2012.

MEJÍA, S. J.; ALBERTÓ, E. Heat treatment of wheat straw by immersion in hot water decreases mushroom yield in Pleurotus ostreatus. Revista Iberoamericana de Micología, 30(2):125-129, 2013.

MENDONÇA, E. S.; MATOS, E. S. Matéria orgânica do solo: Métodos de análises. Viçosa: UFV, 2005. 107p.

NUNES, M. D. et al. Pleurotus ostreatus, mushrooms production using quick and cheap methods and the challenges to the use of coffee husk as substrate. African Journal of Microbiology Research, 11(31):1252-1258, 2017.

RAHMAN, M. H. et al. Effect of wheat bran supplements with rice straw on the proximate composition of oyster mushroom (Pleurotus ostreatus). Bangladesh Research Publication Journal, 7(4):306-311, 2012.

RODRIGUEZ, A. E.; PECCHIA, J. Cultivation of Pleurotus ostreatus. In: ZIED, D. C.; PARDO-GIMÉNEZ, A. Edible and medicinal mushrooms: Technology and applications. Chichester: John Wiley \& Sons Ltd, p.339-360, 2017.

RUGOLO, M. et al. Evaluation of Pleurotus ostreatus basidiomes production on Pinus sawdust and other agricultural and forestry wastes from Patagonia, Argentina. Maderas Ciencia y Tecnología, 22(4):517-526, 2020.

SADH, P. K.; DUHAN, S.; DUHAN, J. S. Agro-industrial wastes and their utilization using solid state fermentation: A review. Bioresources and Bioprocessing, 5(1):1-15, 2018.

SALES-CAMPOS, C. et al. Análise físico-química e composição nutricional da matéria prima e de substratos pré e pós cultivo de Pleurotus ostreatus. Interciencia, 35(1):70-76, 2010.

SALES-CAMPOS, C. et al. Physiochemical analysis and centesimal composition of Pleurotus ostreatus mushroom grown in residues from the Amazon. Food Science and Technology, 31(2):456-461, 2011.

SALES-CAMPOS, C.; ABREU, R. L. S.; VIANEZ, B. F. Condições de uso e processamento de madeira nas indústrias madeireiras de Manaus, Amazonas, Brasil. Acta Amazonica, 30(2):319$331,2000$.

SALES-CAMPOS, C.; ANDRADE, M. C. N. Aproveitamento de resíduos madeireiros para o cultivo do cogumelo comestível Lentinus strigosus de ocorrência na Amazônia. Acta Amazonica, 41(1):1-8, 2011.

SALES-CAMPOS, C.; MINHONI, M. T. A.; ANDRADE, M. C. N. Produtividade de Pleurotus ostreatus em resíduos da Amazônia. Interciencia, 35(3):198-201, 2010.

SARDAR, $\mathrm{H}$. et al. Agro-industrial residues influence mineral elements accumulation and nutritional composition of king oyster mushroom (Pleurotus eryngii). Scientia Horticulturae, 225(18):327-334, 2017.

SARDAR, H. et al. Effects of different culture media, temperature and $\mathrm{pH}$ levels on the growth of wild and exotic Pleurotus species. Pakistan Journal of Phytopathology, 27(2):139145, 2015.

SILVA JÚNIOR, F. G. Utilização múltipla da madeira de Pinus caribaea var. hondurensis para produção de celulose kraft. Série Técnica do IPEF, 9(27):56-62, 1993.

SILVA, E. G. et al. Chemical analysis of fruiting bodies of Pleurotus sajor-caju cultivated in several nitrogen concentrations. Ciência e Tecnologia de Alimentos, 27(1):72-75, 2007.

SINGHAL, S. et al. Mushroom cultivation, processing and valueadded products: A patent based review. Recent Patents on Food, Nutrition \& Agriculture, 10(1):3-19, 2019.

SIQUEIRA, F. G. et al. Cultivation of Pleurotus sajor-caju on banana stalk and Bahia grass based substrates. Horticultura Brasileira, 29(2):199-204, 2011.

ULZIIJARGAL, E.; MAU, J. J. Nutrient compositions of culinarymedicinal mushroom fruiting bodies and mycelia. International Journal of Medicinal Mushrooms, 13(4):343-349, 2011.

VALENZUELA-COBOS, J. D. et al. Chemical composition and biological properties of Pleurotus ssp. cultivated on peat moss and wheat straw. Emirates Journal of Food and Agriculture, 31(11):830-836, 2019.

VOGELMANN, E. S.; PREVEDELLO, J.; REICHERT, J. M. Origem dos compostos hidrofóbicos e seus efeitos em florestas de Pinus e Eucalyptus. Ciência Florestal, 25(4):1067-1079, 2015.

XIONG, S. et al. Energy-efficient substrate pasteurization for combined production of shiitake mushroom (Lentinula edodes) and bioethanol. Bioresource Technology, 274:6572, 2019. 